\author{
ARTIGO \\ d० https://doi.org/10.22481/praxisedu.v16i41.6398
}

\title{
EDUCAÇÃO FÍSICA NA BASE NACIONAL COMUM CURRICULAR: O QUE APREENDER DE DOCUMENTOS E PARECERES OFICIAIS?
}

\author{
PHYSICAL EDUCATION IN THE BASE NACIONAL COMUM CURRICULAR: WHAT \\ TO LEARN FROM DOCUMENTS AND OFFICIAL REPORTS?
}

\author{
EDUCACIÓN FÍSICA EN LA BASE CURRICULAR COMÚN NACIONAL: ¿QUÉ \\ APRENDER DE DOCUMENTOS Y DICTÁMENES OFICIALES?
}

\author{
Ellen Grace Pinheiro \\ Universidade Estadual de Maringá - Brasil \\ Vânia de Fátima Matias de Souza \\ Universidade Estadual de Maringá - Brasil \\ Larissa Michelle Lara \\ Universidade Estadual de Maringá - Brasil
}

\begin{abstract}
Resumo: A presente pesquisa, de caráter descritivo e documental, teve como objetivo analisar a estrutura organizacional da educação física na Base Nacional Comum Curricular (BNCC) por meio de documentos e pareceres oficiais. Para tanto, foi necessário o estudo das quatro primeiras versões da BNCC-Ensino Fundamental e as considerações dos pareceristas. Os seguintes indicadores foram adotados: a) Texto de apresentação da educação física; b) Estruturação do conhecimento por meio das práticas corporais; c) Objetivos gerais/Competências específicas; d) Objetivos de Aprendizagem e/ou desenvolvimento/Habilidades por Prática Corporal; e) Dimensões do Conhecimento; e f) Progressão do Conhecimento. As análises possibilitaram identificar acolhida de algumas sugestões dos pareceristas na Base, assim como oscilações na estrutura organizacional e nas informações quanto à perspectiva da cultura corporal de movimento. Apesar das oscilações e controvérsias, as contribuições dos pareceristas e o documento como um todo são marcados pela preocupação com uma formação educacional democrática e humana.
\end{abstract}

Palavras-chave: Educação Física; Estrutura Organizacional; Base Nacional Comum Curricular.

\begin{abstract}
This descriptive and documentary research aimed to analyze the organizational structure of physical education at the National Common Curricular Base (NCCB) through documents and official reports. For that, it was necessary to study the first four versions of BNCC-Ensino Fundamental and the considerations of the referees. The following indicators were adopted: a) Physical education presentation text; b) Structuring knowledge through bodily practices; c) General objectives/Specific competences; d) Learning and/or development objectives/Skills for Bodily Practices; e) Dimensions of Knowledge; and f) Progression of Knowledge. The analyzes identify the acceptance of some suggestions from the BNCC referees, as well as fluctuations in the organizational structure and in the information regarding the
\end{abstract}


perspective of the body culture of movement. Despite the oscillations and controversies, the contributions of the referees and the documents as a whole are marked by the concern with a democratic and humane educational formation.

Keywords: Physical education; Organizational structure; National Common Curricular Base.

Resumen: Esta investigación descriptiva y documental tuvo como objetivo analizar la estructura organizativa de la educación física en la Base Nacional Común Curricular (BNCC) a través de documentos y dictámenes oficiales. Para eso, fue necesario estudiar las primeras cuatro versiones de BNCC-Ensino Fundamental y las consideraciones de los dictámenes. Se adoptaron los siguientes indicadores: a) Texto de presentación de la educación física; b) Estructuración del conocimiento a través de prácticas corporales; c) Objetivos generales/Competencias específicas; d) Objetivos de aprendizaje y/o desarrollo/Habilidades por práctica corporal; e) Dimensiones del conocimiento; y f) Progresión del conocimiento. Los análisis permitieron identificar la aceptación de algunas sugerencias de los dicatámenes en la Base, así como las oscilaciones en la estructura organizativa y en la información sobre la perspectiva de la cultura corporal del movimiento. A pesar de las oscilaciones y controversias, las contribuciones de los dictámenes y el documento en su conjunto están marcadas por uma aproximación a la formación educativa democrática y humana.

Palabras clave: Educación Física; Estructura organizacional; Base Nacional Común Curricular.

\section{Introdução}

A elaboração, estruturação e fundamentação das políticas educacionais que vislumbram normatizar e/ou orientar os documentos curriculares da educação brasileira configuram-se a partir das relações e interrelações mediadas pelos agentes governamentais, terceiro setor, agências internacionais e movimentos sociais, atrelados a perspectivas ideológicas expressas em sua composição e no projeto de sociedade que se anseia, culminando, dessa forma, em ferramenta de disseminação de um ideário no contexto escolar. Nesse jogo de tensões $\mathrm{x}$ intenções, a Base Nacional Comum Curricular (BNCC) foi gestada, tendo como sustentação um processo construído a partir de analogias políticas e idearias que marcaram governos ambíguos, cujos planos e projeto de sociedade influenciaram diretamente a construção da BNCC, desde o início até sua homologação.

Considerando a temporalidade exequível para a consolidação desse documento, há que se destacar que seu processo de estruturação ocorreu ao longo de 2013 e 2014, contando com eventos/acontecimentos/ações que problematizaram a ideia de uma base comum para o país. O primeiro evento foi o Seminário realizado pelo Conselho Nacional de Secretários de Educação (Consed) e a Fundação Lemann, em outubro de 2013 (MACEDO, 2014); o segundo, foi o Fórum Estadual da União dos Dirigentes Municipais de Educação (Undime), na cidade de São 
Paulo, em março de 2014, também organizado pela Fundação Lemann (MACEDO, 2014); o terceiro foi o $6^{\circ}$ Fórum Nacional Extraordinário, realizado pela Undime, em maio de 2014 (MACEDO, 2014); o quarto foi a audiência pública no âmbito da Comissão de Educação da Câmara de Deputados para debater a formulação de uma base curricular comum para o Ensino Básico do país, em junho de 2014 (SÜSSEKIND, 2014); a quinta ação, ocorrida em julho de 2014, foi a conclusão de um documento pela Secretaria de Educação Básica, de circulação restrita, que foi encaminhado a membros da comunidade acadêmica para apreciações (MACEDO, 2014); o sexto evento, intitulado $3^{\circ}$ Seminário Internacional do Centro Lemann para o Empreendedorismo e Inovação na Educação Brasileira, realizado em agosto de 2014, contou com a palestra "Uma Base Nacional Comum: o potencial e os desafios, em que se discutiu a implementação do Núcleo Comum na Califórnia” (MACEDO, 2014); e a sétima ação, também em agosto de 2014, foi o anúncio, pelo MEC, na mídia nacional, acerca do início do processo de consulta, no âmbito dos estados e municípios, a fim de definir a BNCC, ação ainda incapaz de inaugurar o debate político e sua definição (MACEDO, 2014).

A participação da Fundação Lemann nesses eventos, juntamente com o setor empresarial representado pelo Movimento Todos pela Educação, cujos integrantes também ocupavam cargos em instituições de dirigentes municipais (Undime) e estaduais (Consed), revelou o interesse do mercado nas questões curriculares da década de 2010, que se concretizou como Base Nacional Comum Curricular. Não causa surpresa a influência dessas instituições na educação brasileira, uma vez que também há indícios de ideários advindos de organizações internacionais ${ }^{1}$, também ligadas ao mercado, nas normativas educacionais ${ }^{2}$ que sustentam a Base, como as DCN - 2013, o PNE - 2014-2024 e a LDBN - 1996.

Nesse cenário, a Base começou a ser composta a partir de junho de 2015 (PINHEIRO, 2018) com o I Seminário Interinstitucional para elaboração da BNCC, o qual reuniu assessores e especialistas envolvidos nessa ação. Eles foram instituídos como Comissão de Especialistas por meio da Portaria n ${ }^{\circ}$ 592, de 17 de junho de 2015. Assim, ficou estabelecido que o propósito da BNCC seria o de possibilitar às escolas/redes públicas e particulares brasileiras uma nova organização dos componentes curriculares por meio do seu ideário.

\footnotetext{
${ }^{1}$ Os organismos internacionais que exerceram influência nas questões educacionais brasileiras ao final do século XX e início do século XXI foram: a Unesco, o Banco Mundial, a Cepal, a Unicef, o Pnud, o Preal e a OEI. Cf. Pinheiro (2018).

2 Para entender melhor, cf. Oliveira (2009), Ciavatta e Ramos (2012), Munizi e Arruda (2007), Nogueira (2011) e Pinheiro (2018).
} 
Como ação sequencial, foi inaugurado o Portal da Base, em julho de 2015, visando divulgar a Versão Preliminar da BNCC para que os vários seguimentos da sociedade pudessem participar do processo de composição do documento. Em setembro de 2015, essa Versão Preliminar - Educação Básica foi divulgada ao público e, em maio de 2016, a Segunda Versão - Educação Básica. Desse período em diante, há mudança de governo e das equipes do Ministério da Educação, do Conselho Nacional de Educação (CNE) e daquelas que estavam compondo a Base, gerando, dessa forma, novos contornos ao documento. Assim, em abril de 2017, torna-se pública a Terceira Versão - Educação Infantil e Ensino Fundamental. Em dezembro de 2017, divulga-se a Versão Homologada Educação Infantil e Ensino Fundamental. Em março de 2018, a Terceira Versão - Ensino Médio é apresentada e, finalmente, em dezembro do mesmo ano, a Versão Homologada do Ensino Médio.

De acordo com Pinheiro (2018), esse processo contou com apreciações advindas da internet em três categorias: instituições de ensino público e privado da educação básica, organizações científicas e organizações interessadas na temática e indivíduos (pessoas ligadas à educação ou interessadas). Para a mesma autora, também houve reuniões, seminários e fóruns realizados nos âmbitos municipal, estadual e nacional ao longo de todo o processo, dos quais surgiram relatórios analíticos. Por fim, a BNCC contou com pareceres provenientes de leitores críticos (professores ligados ao ensino superior) e sociedade civil.

Diante do exposto, o objetivo deste estudo foi verificar a estrutura organizacional da Educação Física na Base Nacional Comum Curricular (BNCC), apresentando as considerações de pareceres e relatórios que avaliaram este componente curricular, assim como as análises dos quatro primeiros documentos (Versão Preliminar-2015, Segunda Versão-2016, Terceira Versão-2017a e Versão Homologada-2017b) da Base para o Ensino Fundamental. Tais análises possibilitaram observar o processo de estruturação de um documento a partir de um coletivo bastante diverso de pesquisadores e as oscilações decorrentes da inclusão e exclusão de conceitos e conteúdos com base nas argumentações legitimadas e em relações de poder tecidas/exercidas entre os participantes envolvidos.

\section{Do trato metodológico da pesquisa}

Sustentada pela abordagem qualitativa (MINAYO, 1994), a presente pesquisa amparase metodologicamente nos pressupostos da análise documental (LÜDKE, ANDRÉ, 1986). Para tanto, foram consideradas as seguintes fontes primárias: seis pareceres dos leitores críticos da 
Primeira Versão da BNCC - Educação Física (P1V1³ , 2016; P2V1, 2016; P3V1, 2016; P4V1, 2016; P5V1, 2016; P6V1, 2016), e quatro da Terceira Versão - Educação Física (P1V3, 2017; P2V3, 2017; P3V3, 2017; P4V3, 2017), o Relatório - "Números finais das contribuições propostas ao componente curricular educação física" do documento Preliminar da BNCC (BRASIL, 2016b), mais sete pareceres da sociedade civil ${ }^{4}$ (PC1V3, 2017; PC2V3, 2017; PC3V3, 2017; PC4V3, 2017; PC5V3, 2017; PC6V3, 2017; PC7V3, 2017) enviados ao Conselho Nacional de Educação e as quatro primeiras Versões da Base já mencionadas. A adoção desses documentos primários deu-se de forma intencional, subscrita por sua temporalidade de escrita. Considerou-se como critério de elegibilidade os documentos disponíveis ao público, constantes na íntegra. Foram realizadas leitura e análise da Base, especialmente no tocante ao componente educação física, com extração de conteúdos que atendessem diretamente aos objetivos da investigação. $\mathrm{O}$ mesmo ocorreu em relação aos pareceres, relatórios e quatro versões da Base para o ensino fundamental, cuja ordem de análise foi determinada pelo acesso das pesquisadoras às fontes de pesquisa.

Os documentos anteriormente nominados foram admitidos como fonte primária da pesquisa pois, de acordo com Santos (2000), projetos de lei, pareceres, ofícios, discursos, informativos, depoimentos (orais e escritos), notas, diários, mapas, testamentos, documentos informativos arquivados em repartições públicas, entre outros, compreendem fontes documentais. Tal entendimento é corroborado por Marconi e Lakatos (2010, p. 157) ao afirmarem que uma das “[...] características da pesquisa documental é que a fonte de coleta de dados está restrita a documentos, escritos ou não, constituindo o que se denominam fontes primárias. Nesse sentido, leituras de documentos (conforme o acesso das pesquisadoras a eles), demarcação de partes consideradas atinentes aos objetivos da pesquisa, assim como a extração de excertos potentes para as reflexões relativas ao processo de construção da Base foram caminhos metodológicos assumidos pelas autoras para o desenvolvimento investigativo.

A proposta de análise observou a organização dos seguintes constructos nos documentos investigados: 1) Texto de apresentação do componente educação física; 2) Estruturação do conhecimento da educação física por meio das práticas corporais; 3) Objetivos gerais do componente educação física, Objetivos de Aprendizagem (Gerais) e Competências específicas da educação física; 4) Objetivos de Aprendizagem, Objetivos de Aprendizagem e

\footnotetext{
${ }^{3}$ A letra P refere-se a parecer. Os números são os leitores classificados por ordem alfabética. O V é de Versão e o número, na sequência, faz menção a sua ordem de Versão. Exemplo P1V1, parecer 1 da Versão Preliminar.

${ }^{4} \mathrm{~A}$ letra $\mathrm{P}$ é de parecer, a letra C é de civil e o V indica a Versão. Exemplo: PC1V3 significa parecer civil 1 da Terceira Versão.
} 
Desenvolvimento e Habilidades por Prática Corporal; 5) Dimensões do Conhecimento; e 6) Progressão do Conhecimento ao longo das etapas (e entre as etapas) de escolarização. Tais tópicos compõem a sequência desse artigo e foram elencados em formato e ordem semelhantes aos apresentados nos textos das Versões da BNCC. Espera-se que essa produção textual possa instituir elementos para a análise da conjuntura relacionada à estruturação de documento educacional, observando-se nuances e relações de poder que perpassam esse processo.

\section{Incursões pela especificidade do componente curricular Educação Física na Base}

Na Versão Preliminar da Base, o componente Educação Física contou com a colaboração de uma equipe formada por treze pessoas, chamada de especialistas, entre eles, professores ligados ao ensino superior e professores relacionados ao Consed e à Undime. A Segunda Versão considerou as apreciações advindas de vários seminários nos âmbitos municipais e estaduais e àquelas oriundas da internet, sendo que sua avaliação e composição também se deu pela mesma equipe de especialistas. Após o “[...] golpe político-jurídico de maio de 2016 [...]” (NEIRA, 2018, p. 215), a Terceira Versão do componente passa por novas apreciações, sendo composta por apenas duas pessoas da equipe inicial de especialistas. A Versão Homologada-Educação Infantil e Ensino Fundamental, por sua vez, contou com a participação da equipe do MEC. Ao final desse mesmo documento, contudo, aparecem os nomes das mesmas duas pessoas da equipe de especialistas da Terceira Versão, dando a entender que o documento homologado é o mesmo do anterior. Apesar disso, observam-se algumas alterações no texto.

\section{1 Apresentação do componente da Educação Física na BNCC}

Para compreender melhor o processo de escrita e de apreciações da BNCC, voltamonos, primeiramente, para a Versão Preliminar, primeiro tópico, que se refere ao texto de apresentação do componente da Educação Física. Nele são suscintamente mencionados os esforços empreendidos pela educação física para se alinhar a propósitos republicanos e para possibilitar às próximas gerações os conhecimentos científicos e culturais sistematizados. Também são mencionados aspectos relacionados à cultura corporal de movimento, ao fato de as práticas corporais estarem nessa perspectiva, à responsabilidade desse componente na escola, aos desafios a serem superados, à progressão dos conhecimentos e aos objetivos de aprendizagem gerais e específicos (BRASIL, 2015). 
Nesse sentido, P1V1 (2016) afirmou que, na explanação da Base, atribui-se à educação física o contato com práticas corporais promovidas apenas por esse componente na escola e que, diferentemente, essas práticas corporais podem ser vivenciadas em outros espaços socioculturais. P1V1 (2016) também relatou que um excerto apresentou as manifestações da cultura corporal sem o termo movimento, sendo necessário corrigir e alinhar delimitações. Assim como P1V1 (2016), também entendemos que as práticas corporais atinentes à cultura corporal de movimento mencionadas na BNCC podem ser vivenciadas em outros espaços que não seja a escola, algo não evidenciado no texto, sobretudo, pela forma como são elencadas as finalidades ${ }^{5}$ da Base e da própria cultura corporal de movimento.

P5V1 (2016, p. 3) relatou que o referido texto não elucida o aporte teórico e nem a concepção dos termos práticas corporais e cultura corporal de movimento, pois “"...] confunde o leitor e fragiliza a construção de aporte para superar os 'desafios didáticos' e de estratégias para o ensinar". De fato, essas lacunas são observadas, entretanto, fica aparente que a perspectiva assumida está relacionada à cultura. Nesse sentido, Neira e Souza Júnior (2016, p. 197) explicam que "na perspectiva adotada pela BNCC, cultura é toda e qualquer ação social que expressa ou comunica um significado, tanto para quem dela participa e constrói quanto para quem observa, aprecia e usufrui.".

Ao buscar referenciais da área para o entendimento do conceito de cultura corporal de movimento, Bracht (1999) explica que, sob esse ponto de vista, o movimentar-se é uma forma de comunicação com o mundo que é constituinte, construtor de cultura e possibilitada por ela; é, também, linguagem específica e, como cultura, habita o mundo do simbólico. Assim,

[...] fazem parte da cultura corporal de movimento todos os saberes e discursos que envolvem as práticas corporais, desde as regras da amarelinha até o desenho tático do futebol, passando pelas técnicas do balé, a história do judô e os efeitos gerados pelos exercícios de musculação. [...]. A cultura corporal de movimento é o próprio conteúdo das aulas, pois se trata do conhecimento específico que qualificará a leitura que as crianças, jovens e adultos fazem das práticas corporais disponíveis na sociedade, bem como a sua reconstrução crítica na escola. (NEIRA; SOUZA JÚNIOR, 2016, p. 196-197).

Em relação à concepção de práticas corporais, também mencionada por P5V1 (2016), de fato o documento não traz densos esclarecimentos. Contudo, é possível observar a seguinte compreensão:

[...] práticas corporais em suas diversas formas de codificação e significação social, [são] entendidas como manifestações das possibilidades expressivas

\footnotetext{
${ }^{5}$ Essas finalidades podem ser compreendidas por meio dos objetivos gerais e específicos de aprendizagem da educação física que são mencionados nas páginas 97 a 114 (BRASIL, 2015).
} 
dos sujeitos e do patrimônio cultural da humanidade, produzidos por diversos grupos sociais no decorrer da história. (BRASIL, 2015, p. 95).

Este excerto vai ao encontro da concepção de Neira e Souza Júnior (2016, p. 195), de que, na perspectiva da cultural do movimento, as práticas corporais são compreendidas como aquelas "[...] concebidas como textos da cultura [...], como "[...] produtos da gestualidade, formas de expressão e comunicação passíveis de significação, ou seja, artefatos da cultura produzidos por meio da linguagem corporal.”. Elas também se configuram, antes de qualquer coisa, como "produtos culturais de um determinado grupo, [...] como um fator de identidade cultural, situadas num tempo e espaço social.” (NEIRA; SOUZA JÚNIOR, 2016, p. 198).

Seguindo as considerações dos pareceristas, P2V1 (2016, p. 7) relatou que "[...] o texto que apresenta o componente curricular Educação Física precisa ser adensado com a inclusão e ou aprofundamento de aspectos concernentes à especificidade pedagógica da EF”. P6V1 (2016) propôs a ampliação do 'espaço’ da educação física na BNCC. P3V1 (2016) elogiou o argumento de que a educação física pode gerar conhecimento específico insubstituível de sua responsabilidade e acrescentou a importância de dar lugar de destaque, no documento, às finalidades específicas desse componente. Já os dados da Consulta Pública demonstraram que, nos quesitos "clareza" e "pertinência e relevância", os participantes (em sua maioria) afirmaram "concordo", seguido de "concordo fortemente" com a proposta apresentada (BRASIL, 2016b).

$\mathrm{Na}$ Segunda Versão, o texto da educação física buscou trazer elementos que explicassem sucintamente sua constituição (elementos fundamentais a todas as práticas corporais) e sua importância no processo de escolarização, adensando-os com questões organizacionais e pedagógicas referentes à relevância social do componente para os estudantes. Talvez essa ação não tenha atendido totalmente à solicitação de P2V1 (2016) acerca do aprofundamento de aspectos pedagógicos específicos do componente, mas atendeu, de alguma forma, à consideração de P6V1 (2016) sobre a ampliação do 'espaço' da educação física na BNCC, pois esta Versão é a maior entre as quatro primeiras.

A imprecisão na escrita, revelada na menção aos termos cultura corporal de movimento e cultura corporal, comentado por P1V1 (2016), passa a ser revista nessa Versão, haja vista as orientações epistemológicas que destacam diferenciações, tanto em termos de fundamentação teórica quanto de práticas corporais acerca dessas perspectivas. Verificou-se também a tentativa de dar mais ênfase ao argumento de que esse componente gera um conhecimento específico insubstituível, como enaltecido por P3V1 (2016), assim como a inserção de trechos que 
justificam a proposta culturalista ${ }^{6}$ como, por exemplo, o que menciona que essa perspectiva já constava nos Parâmetros Curriculares Nacionais. Esses acréscimos de informações foram possibilitados pelo maior espaço que a educação física teve no documento, entretanto, constatase que não houve esclarecimentos quanto à adoção do aporte teórico.

$\mathrm{O}$ excerto que mencionava que a educação física propiciaria ao sujeito o contato com práticas corporais promovidas apenas por esse componente, algo que recebeu crítica de P1V1 (2016), foi reescrito na Segunda Versão, mas leva o mesmo entendimento da Versão Preliminar. Nesse documento, o texto segue sem elucidar o aporte teórico e a cultura corporal de movimento, algo solicitado por P5V1 (2016), contendo apenas esclarecimentos para o termo práticas corporais, assim como na Versão anterior.

No texto de apresentação do componente, na Terceira Versão, houve a exclusão de excertos que davam a entender, minimamente, o porquê de a BNCC optar por uma proposta culturalista. Nesse sentido, não se identifica uma justificativa consistente para essa escolha. Foram suprimidos os elementos que explicavam a constituição do componente, mas em síntese, se mantiveram: os elementos fundamentais a todas as práticas corporais, a importância do componente no processo de escolarização/relevância social para os educandos (bem como questões organizacionais e pedagógicas) e o argumento de que esse componente gera um conhecimento específico insubstituível.

Verificou-se, também que, o espaço ocupado pela educação física na BNCC, assim como os demais componentes, fora reduzido, desconsiderando a solicitação de P6V1 (2016) que foi atendida na Segunda Versão e descontinuada nessa. O excerto mencionado por P1V1 (2016) acerca do fato de as práticas corporais serem promovidas na escola apenas pela educação física segue na proposta e leva o mesmo entendimento já criticado por essa parecerista.

O texto dessa Versão também não informa o aporte teórico e nem o conceito de cultura corporal de movimento, requisitado por P5V1 (2016). Apenas informa que "[...] o movimento humano está sempre inserido no âmbito da cultura e não se limita a um deslocamento espaçotemporal de um seguimento corporal ou de um corpo todo." (BRASIL, 2017a, p. 171). O texto suprimiu a explicação acerca das práticas corporais e focou na importância da vivência da prática pedagógica. Também não se observa adensamento dos aspectos pedagógicos específicos do componente, como solicitado por P2V1 (2016).

\footnotetext{
6 A proposta culturalista, no contexto da educação física, compreende aos saberes culturais tratados pelo componente e criados pelo homem ao longo de sua história, os quais, não incluem o estabelecimento de níveis de complexidade motora por ano escolar.
} 
Um dos leitores críticos da Terceira Versão da BNCC - P4V3 (2017) - contesta vários aspectos do documento. A primeira consideração vem em formato de sugestão de ajuste e refere-se ao fato de a educação física se enquadrar nos conceitos da Base, igualando-se "[...] às disciplinas de cunho cognitivo/racionalista/conteudista, que apresentam objeto de estudo claro e sistematização cronológica em suas tradições.” (P4V3, 2017, p. 17). Assim, ele propõe que a educação física seja desencaixada de tais conceitos da BNCC para acomodar as particularidades que o componente traz para a escola, o que pode ser pensado com as outras disciplinas (artes, danças, músicas, teatro). Esta nova organização “[...] poderia tentar afirmar nossas diferenças das outras disciplinas, sem preconceitos ou sentimentos de inferioridade, apresentando uma proposta que marque identidade e contribua para a construção do conhecimento sem romper com as idiossincrasias mais caras que une a comunidade da Educação Física no chão da escola." (P4V3, 2017, p. 17).

Na segunda contestação, P4V3 (2017, p. 6) considerou que o texto do componente curricular educação física apontou para a “[...] diversidade de práticas corporais disponíveis no acervo cultural, mas não indica como esse acervo vem crescendo e se diversificando [...]" na atualidade. Na terceira contestação, P4V3 (2017) relatou que o texto sobre a formação geral dos alunos não trouxe esclarecimentos sobre qual seria a contribuição específica da educação física e nem quais competências seriam aprendidas. Em relação à terceira crítica, é necessário mencionar que, embora esse documento tenha suprimido várias informações relevantes, ele materializa o que se objetiva em termos gerais ao mencionar as competências específicas do componente e também ao relatar aspectos da contribuição do componente via entendimento das práticas corporais como fenômeno cultural, conforme trecho a seguir:

[...] é possível assegurar aos alunos a (re)construção de um conjunto de conhecimentos que permitam ampliar sua consciência a respeito de seus movimentos e dos recursos para o cuidado de si e dos outros e desenvolver autonomia para apropriação e utilização da cultura corporal de movimento em diversas finalidades humanas, favorecendo sua participação de forma confiante e autoral na sociedade. (BRASIL, 2017a, p. 171).

A quarta consideração, realizada por P4V3 (2017), menciona que a proposta culturalista esforçou-se em dialogar com a área de Linguagens, mas abandonou as tradições e a integralidade dos saberes do componente. A quinta contestação referiu-se ao fato de o texto anunciar o locus “[...] das práticas corporais fora de propósitos específicos e instrumentais, delimitando-os apenas no lazer e no cuidado com a saúde [...]", além de valorizar algumas aprendizagens pretendidas como "vivenciar (experimentar na prática) e aprender a jogar melhor 
(para se divertir e cuidar da saúde)." (P4V3, 2017, p. 8). Para o parecerista, a quinta crítica excluiu o universo profissionalizante do esporte, ou seja, excluiu o entendimento de que a educação física poderia, de forma crítico-reflexiva, provocar nos alunos o interesse por uma carreira profissional e que essa pode nascer da experiência do praticar/conhecer as diversas modalidades esportivas. Assim, ele entende que a função escolar, nessa direção, seria legítima, pois a educação física não é menor do que outras profissões que a escola se orgulharia em promover.

Por fim, na sexta crítica, P4V3 (2017) questionou a ausência da psicomotricidade na Base e a inserção da proposta culturalista. Para ele, a psicomotricidade é uma prática corporal pedagógica, por origem e excelência, que visa responder às necessidades das crianças com dificuldades nas aprendizagens escolares, ao passo que a proposta culturalista desarticula qualquer chance de sistematização da alfabetização motora, não apresentando elementos que atendam a essa finalidade.

PC5V3 (2017, p. 1), por sua vez, discordou do conceito de práticas corporais presente na BNCC, alegando a "ausência de pautas comportamentais", uma vez que esse conceito não responde ao "[...] panorama internacional de sedentarismo e inatividade em crianças e adolescentes" e às enfermidades que "[...] comprometem o desenvolvimento (como a obesidade, hipertensão e a diabetes que são fatores de risco para o câncer e outras doenças)". Ele citou as recomendações da Organização Mundial da Saúde (OMS) e da Unesco, destacando a escola como “[...] espaço primeiro e privilegiado, para a implementação de políticas públicas de promoção da saúde" (PC5V3, 2017, p. 2). Alegou também que esse seria um momento histórico e oportuno para corrigir essa distorção e questionou o fato de não ser possível “"...] responsabilizar pais, professores, gestores escolares e a classe política[...]" pela adoção de estilos de vida saudáveis, aptidão física para saúde e alfabetização motora (PC5V3, 2017, p. 2).

P1V3 (2017) relatou que entender o movimento é essencial para as práticas corporais, as quais devem ser o principal norteador do componente educação física. Em complemento, o mesmo parecerista reconheceu a importância de se desenvolver a proficiência motora. Já PC6V3 (2017) discorreu acerca do legado educacional dos Jogos Olímpicos, ressaltando que o “analfabetismo motor" deveria ser corrigido. PC6V3 (2017, p. 2) também sugeriu que, no texto da educação física, fossem inseridos os quatro pilares da Panathlon: "Valores Olímpicos, Amizade, Cultura e Fair Play”. Por sua vez, PC2V3 (2017, p. 2-3) relatou, em seu parecer, que as políticas públicas do MEC deveriam: 
[...] convergir com as políticas públicas do Ministério da Saúde assumindo compromissos de diminuir a obesidade da população brasileira, por meio do Programa de Saúde da Família, do Programa Saúde Brasil e do Programa Academia da Saúde, entre outras ações que contribuem para a promoção da saúde e prevenção a fim de reduzir a mortalidade prematura por Doenças Crônicas Não Transmissíveis (DCNT).

Dessa forma, PC2V3 (2017), entende que as políticas públicas teriam que se voltar ao atendimento das recomendações nacionais, entre elas, a de que o componente auxilie as crianças a desenvolverem padrões de comportamento que as mantenham fisicamente ativas ao longo da vida.

A preocupação com a psicomotricidade, a alfabetização motora/desenvolvimento motor, o analfabetismo motor, a proficiência motora, as pautas comportamentais ou problemas relacionados a saúde/enfermidades, foram bastante citados nos pareceres. Mas, será que a educação física escolar pode contribuir para corrigir certas distorções ou promover com excelência essas questões apenas com duas aulas semanais? E, em uma perspectiva cultural, é esse o objetivo da educação física?

De acordo com Neira (2011, p. 196), “com aulas focadas nas habilidades motoras, na aprendizagem esportiva ou nas noções monoculturais de saúde e cuidado com o corpo, dificilmente se possibilitará a construção de subjetividades mais abertas ao trato da diversidade.”. Nesse sentido, quando a educação física é baseada “[...] unicamente em comportamentos motores e padrões físicos, a diversidade cultural é ocultada, retirando dos alunos seus traços identitários." (NEIRA, 2011, p. 198). Por essa razão, Neira (2011) afirma:

[...] dada a importância política e pedagógica do compromisso de formar identidades culturais democráticas e atender à diversidade cultural da sociedade, são bem-vindos todos os currículos que rompam com a tradição da área (elitista, excludente, classificatória e monocultural).

Quanto à psicomotricidade, Bracht (1992) observa-se que há um deslocamento da 'educação do movimento' para a 'educação pelo movimento', ficando a primeira em segundo plano. Essa compreensão, a nosso ver, denota a possível inviabilidade de considerar a 'educação do movimento' mais adequada para as finalidades que a Base aponta, pois, em linhas gerais, a psicomotricidade desloca a finalidade da educação física, em promover os conhecimentos relativos às várias manifestações corporais, para perceber o movimento em inúmeras aprendizagens relacionadas a outros componentes curriculares. Em complemento, Daolio (1996) auxilia nessas questões ao afirmar que o objetivo da educação física em uma perspectiva cultural não será a aptidão física e nem o melhor rendimento esportivo dos alunos. 
Ao optar pela perspectiva cultural/cultura corporal de movimento, a Base não atende às solicitações de P4V3 (2017), PC5V3 (2017), P1V3 (2017) e PC6V3 (2017), as quais sugeriam que as aulas de educação física na escola fossem voltadas à promoção da saúde e demais problemas (obesidade, sedentarismo e enfermidades, por exemplo). Essas solicitações estavam em desacordo com a perspectiva da BNCC, orientada por uma educação física que potencialize as diversas experiências corporais dos alunos, considerando seu universo cultural, sua subjetividade e suas relações sociais.

O documento Recomendações globais da atividade física para a saúde, disseminado pela Organização Mundial da Saúde (WHO, 2011), relata que evidências científicas apontam para os benefícios da atividade física para a saúde voltados à faixa etária de 5 a 17 anos. Em níveis adequados, esses benefícios contribuem para o desenvolvimento de tecidos musculoesqueléticos saudáveis; sistema cardiovascular saudável; consciência neuromuscular; e facilita a manutenção de um peso corporal saudável. Para tanto, é requisitado que crianças e adolescentes façam, pelo menos, 60 minutos de atividade física diariamente, moderada a vigorosa. Já a Organização das Nações Unidas (ONU, 2018) também recomenda que crianças e adolescentes (de 5 a 17 anos) pratiquem atividade física com intensidades moderada a intensa, por 60 minutos diariamente. Também preconiza exercícios que incluam fortalecimento de ossos e músculos, pelo menos, três vezes na semana.

Diante disso, será que duas únicas aulas semanais, 45 ou 50 minutos, podem resolver os problemas relacionados à saúde, além de promovê-la? Ao que tudo indica, não, e por algumas razões. A primeira delas refere-se ao tempo disponível para as aulas, o qual não atende às recomendações da OMS ou da ONU para a faixa etária e nem em relação à intensidade diária. A segunda razão é que a Base, ao indicar competências específicas, requisita uma série de ações que envolvem discussões e reflexões para que os alunos sejam críticos; isso significa que eles não ficarão as duas aulas semanais apenas praticando alguma manifestação corporal. A terceira razão orienta-se pelo entendimento de que as aulas de educação física não se caracterizam como treino esportivo. A quarta razão considera que há muitas práticas corporais a serem contempladas pelos alunos ao longo do ano e que não é adequado trabalhar apenas com certos padrões motores, o que, consequentemente, implica em não possibilitar excelência em desenvolvimento motor a todos os alunos e, sim, maior vivência nas várias manifestações da cultura corporal. A quinta razão é que todas essas solicitações dos pareceristas também ficam em desacordo com a perspectiva cultural que orienta a Base. 
Em relação à solicitação para que as políticas públicas do MEC convergissem com as do Ministério da Saúde, algo que norteia o parecer de PC2V3 (2017), entendemos que há possibilidade de que os professores de educação física conscientizem os alunos acerca da obesidade e demais problemas de saúde, indicando hábitos saudáveis para a vida. Contudo, as temáticas discutidas nesses espaços não se resumirão apenas a esses assuntos e, caso seja necessária atenção especial para alguma dessas questões, o Ministério da Saúde deve se encarregar disso por meio de políticas públicas específicas.

A penúltima solicitação da Terceira Versão é feita por PC1V3 (2017). Nela, a parecerista afirma que essa Versão teve como foco principal "ora o aluno", "ora o conhecimento", e que também houve "excesso de exemplos de conteúdos" que acabam se configurando como modelos que podem inibir "a autonomia das instituições de ensino" (PC1V3, 2017, p. 1). Para ela, seria necessário trabalhar a percepção corporal, possibilitando várias aprendizagens. Contudo, em nosso entendimento, esses exemplos não atrapalham e, sim, auxiliam as escolas/redes/professores a terem elementos para o entendimento do que a BNCC objetiva.

Por último, PC3V3 (2017) mencionaram a necessidade de estabelecer um objetivo claro para o componente educação física na escola. De fato, também entendemos que esses objetivos não estavam muito elucidativos, remetendo à necessidade de busca de informações complementares em outros documentos. O que se verifica no texto são descrições sucintas acerca da finalidade da educação física.

$\mathrm{Na}$ Versão Homologada, o texto do componente educação física foi reescrito, embora haja a preservação das mesmas ideias da Versão anterior, em sua maior parte. Em relação ao uso das práticas corporais (lazer/entretenimento e/ou o cuidado com o corpo e a saúde), criticado por P4V3 (2016), Neira (2018) afirma que a BNCC desconsidera que as práticas corporais possam ser significadas, socialmente, de outras maneiras, para além do lazer ou da saúde, incluindo, por exemplo, o campo do exercício profissional, da competição, da religiosidade, da estética, o que configura uma incoerência, pois o próprio texto assume tal posicionamento.

Ainda em relação a esse documento, a solicitação de esclarecimentos para a justificativa da proposta culturalista, requisitada pelos leitores críticos da Primeira Versão, foram desconsiderados. A psicomotricidade não consta no documento, assim como também não constam a alfabetização motora/desenvolvimento motor, o analfabetismo motor, a proficiência motora, as pautas comportamentais ou situações que auxiliassem os educandos a superarem o 
sedentarismo, a obesidade e outras enfermidades. Os quatro pilares mencionados por PC6V3 (2017) não foram materializados no texto, mas são valores comuns à vida social dos educandos e podem ser estimulados nas aulas de educação física, ao longo do ano escolar.

\subsection{Estruturação do conhecimento da educação física por meio das práticas corporais}

$\mathrm{Na}$ Versão Preliminar e na Segunda Versão, a estruturação dos conhecimentos da educação física deu-se por meio dos objetivos de aprendizagem específicos por práticas corporais que, por sua vez, foram distribuídas ao longo dos ciclos de escolarização. A diferença entre a Versão Preliminar e a Segunda Versão, para além da terminologia dos objetivos, destaca-se pela inserção de quadros e explicações acerca de cada prática corporal, ao longo dos ciclos, que passa a compor esse segundo documento. O Quadro 1 demonstra a estrutura organizacional das práticas corporais por ciclos de escolarização.

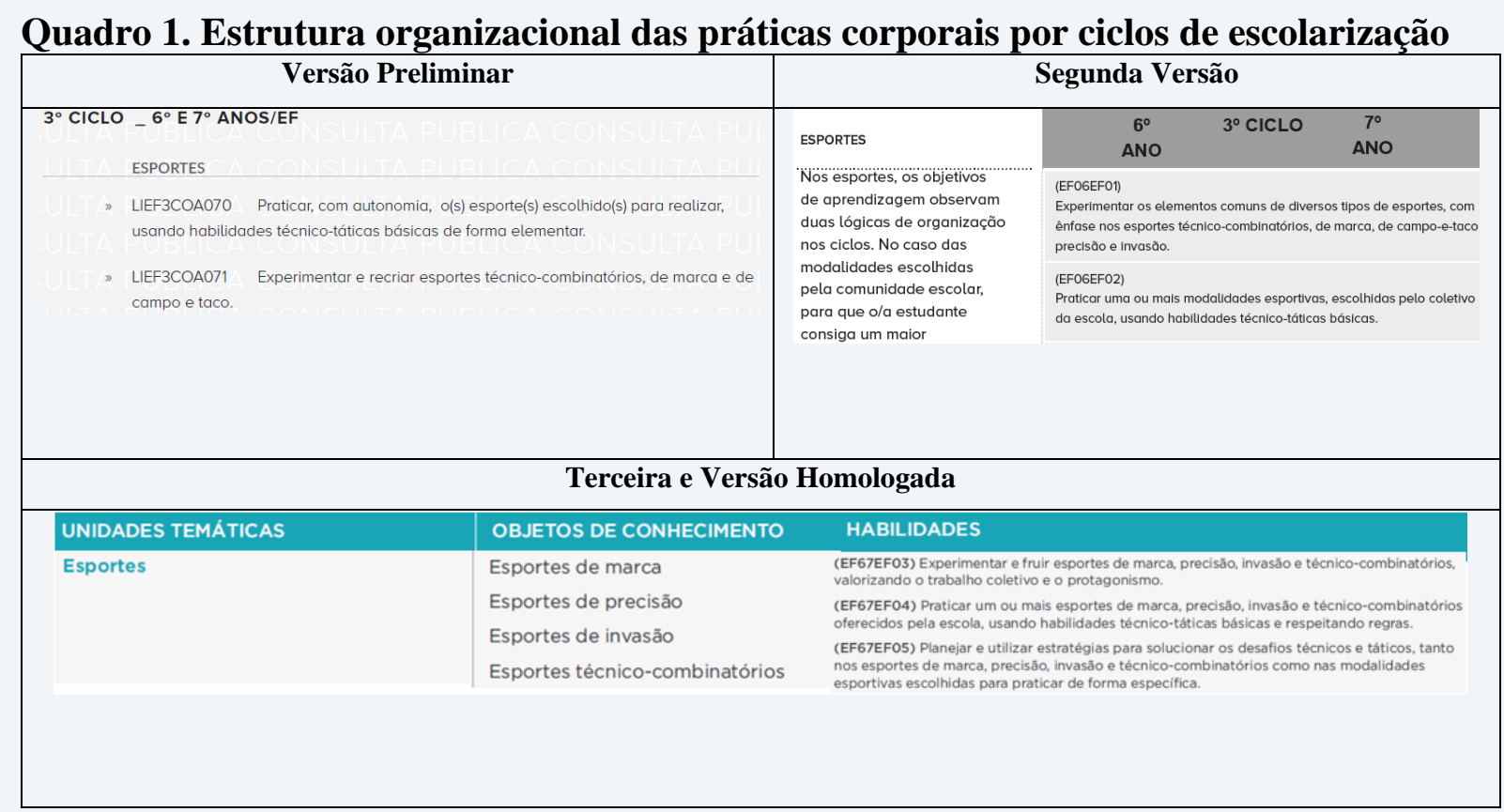

Fonte: elaborado pelas autoras. Adaptado de Brasil (2015; 2016a, 2017a; 2017b).

Na Terceira Versão e na Versão Homologada, as explicações acerca de cada prática corporal foram suprimidas. As práticas corporais também foram inseridas em quadros, sendo designadas de "unidades temáticas"; os conhecimentos a serem trabalhados em cada uma delas foram nomeados de "objetos de conhecimento" (BRASIL, 2017a; 2017b). Quanto a esses dois novos termos, há considerações de três pareceres da Terceira Versão. O primeiro deles, de P2V3 (2017), julgou inapropriado o uso dos termos sem a devida explicação e sugeriu que eles fossem 
melhor elucidados e detalhados. P4V3 (2017) mencionou que a descrição das Unidades Temáticas é restritiva, simplista e não segue um padrão. O parecer de PC3V3 (2017) solicitou que fosse feito um "sequenciamento das unidades temáticas" e que se justificassem os termos unidades temáticas e objetos de conhecimento.

$\mathrm{Na}$ Versão Homologada, as unidades temáticas e os objetos de conhecimentos preservaram a mesma estrutura da Terceira Versão, porém, eles não foram explicados no texto. Houve uma única alteração em um objeto de conhecimento do $2^{\circ}$ ciclo da prática corporal lutas, o qual, foi acrescido às lutas de matriz africana e indígena. Assim como na Terceira Versão, nessa Versão Homologada permaneceu a exclusão das explicações das práticas corporais que constavam nos quadros, algo presente na Segunda Versão. Portanto, as solicitações de P2V3 (2017) e PC3V3 (2017) não foram atendidas. As descrições das Unidades Temáticas seguem de forma simplista e sem qualquer padrão, algo criticado por P4V3 (2017).

\subsection{Objetivos Gerais do componente Educação Física, Objetivos de Aprendizagem (Gerais) e Competências Específicas da Educação Física}

A Versão Preliminar da BNCC menciona, em seu texto, o termo Objetivos de Aprendizagem (gerais e específicos) e Objetivos Gerais do componente educação física. Nesse sentido, observa-se que a terminologia não segue um padrão, nem tampouco o que foi indicado pelo PNE (2014) para o ensino fundamental, "objetivos de aprendizagem e desenvolvimento".

Nessa Versão, foram elencados nove Objetivos Gerais para a Educação Física, os quais visavam favorecer "[...] a apropriação, a problematização e o uso criativo dos conhecimentos específicos [...]” da área na escola (BRASIL, 2015, p. 97). Ao analisar esses objetivos, P5V1 (2016) os considerou adequados e parcialmente pertinentes. P1V1 (2016) relatou que havia a necessidade de se observar o uso de certos termos e P3V1 (2016) sugeriu a substituição de alguns deles.

Na Segunda Versão observou-se uma organização diferente, sem objetivos gerais para o componente. Para os anos iniciais do ensino fundamental não constam objetivos e, para os anos finais, há dez objetivos, embora, no documento, a nomenclatura adotada seja Metas. A nosso ver, ao optar por objetivos gerais separados por nível de ensino, essa versão da BNCC deveria ter elencado objetivos para todos os níveis e padronizado a nomenclatura, dada a normativa que baliza o termo. 
Libâneo (1990, p. 122) entende que "os objetivos são o ponto de partida, as premissas gerais do processo pedagógico" e, no caso dos objetivos gerais, expressam propósitos mais amplos. Nesse sentido, a Segunda Versão, ao não trazer objetivos gerais para os anos iniciais da educação física, descaracterizou as intencionalidades gerais desse componente.

Na Terceira Versão, notou-se o retorno dos objetivos gerais, porém, nesse documento, com a nomenclatura Competências Específicas. Esse é um termo que advém do documento geral, que não foi pactuado de maneira interfederativa ${ }^{7}$, como previsto no PNE (2014) e, também, não consta nas DCN (2013) para a educação básica. O Quadro 2 demonstra sucintamente a estrutura ao longo das quatro Versões bem como a quantidade de objetivos/metas/competências, dimensões e habilidades.

Quadro 2. Estrutura sucinta das quatro Versões da BNCC

\begin{tabular}{|c|c|c|c|}
\hline \multicolumn{4}{|c|}{ Educação Física } \\
\hline $1^{\text {a }}$ Versão & $2^{\text {a }}$ Versão & $\begin{array}{c}3^{\mathbf{a}} \text { Versão } \\
\text { Ensino Fundamental } \\
\end{array}$ & $\begin{array}{l}\text { Versão Homologada } \\
\text { Ensino Fundamental }\end{array}$ \\
\hline $\begin{array}{c}\text { Objetivos Gerais - } \\
\text { Ensino Fundamental e } \\
\text { Médio: } 9\end{array}$ & ------------------------ & $\begin{array}{l}\text { Competências } \\
\text { Específicas Ensino } \\
\text { Fundamental: } 11\end{array}$ & $\begin{array}{l}\text { Competências } \\
\text { Específicas Ensino } \\
\text { Fundamental: } 10\end{array}$ \\
\hline & $\begin{array}{c}\text { Objetivos de } \\
\text { Aprendizagem para o } \\
\text { Ensino Fundamental } \\
\text { - Anos Iniciais: ----- } \\
\text { Metas para o Ensino } \\
\text { Fundamental - Anos } \\
\text { Finais: } 10 \\
\text { Objetivos de } \\
\text { Aprendizagem para o } \\
\text { Ensino Médio: } 10\end{array}$ & & \\
\hline $\begin{array}{c}\text { Objetivos de } \\
\text { Aprendizagem } \\
\text { Específicos por prática } \\
\text { corporal em ciclos }\left(1^{\circ}\right. \\
\underline{\left.\text { ao } 5^{\circ} \text { ciclo }\right)}\end{array}$ & $\begin{array}{c}\text { Objetivos de } \\
\text { Aprendizagem e } \\
\text { Desenvolvimento por } \\
\text { ciclos }\left(1^{\circ} \text { ao } 4^{\circ} \text { ciclo) }\right. \\
\begin{array}{c}\text { Objetivos de } \\
\text { Aprendizagem } 5^{\circ} \\
\text { ciclo }\end{array}\end{array}$ & $\begin{array}{l}\text { Habilidades por ciclo- } \\
\text { práticas corporais }\end{array}$ & $\begin{array}{l}\text { Habilidades por ciclo- } \\
\text { práticas corporais }\end{array}$ \\
\hline $\begin{array}{c}\text { Dimensões do } \\
\text { Conhecimento: } 6 \\
\end{array}$ & $\begin{array}{c}\text { Dimensões do } \\
\text { Conhecimento: } 8\end{array}$ & $\begin{array}{c}\text { Dimensões do } \\
\text { Conhecimento: } 8 \\
\end{array}$ & $\begin{array}{c}\text { Dimensões do } \\
\text { Conhecimento: } 8 \\
\end{array}$ \\
\hline $\begin{array}{c}\text { Cultura Corporal de } \\
\text { Movimento }\end{array}$ & $\begin{array}{c}\text { Cultura Corporal de } \\
\text { Movimento }\end{array}$ & $\begin{array}{c}\text { Cultura Corporal de } \\
\text { Movimento }\end{array}$ & $\begin{array}{l}\text { Cultura Corporal de } \\
\text { Movimento }\end{array}$ \\
\hline
\end{tabular}

Fonte: elaborado pelas autoras. Adaptado de Brasil (2015; 2016a, 2017a; 2017b).

\footnotetext{
${ }^{7}$ A Pactuação interfederativa previa que as diretrizes pedagógicas e a construção de uma base comum deveriam ser balizadas em regime de colaboração entre a União, Estados, Municípios e Distrito Federal (BRASIL, 2014).
} 
Para tentar justificar o termo competências, o documento geral trouxe alguns artigos da LDBN (1996). O artigo 9, inciso IV, menciona que a União deve estabelecer, em colaboração com Municípios, Estados e Distrito Federal competências e diretrizes para a educação básica. O referido documento utilizou também os artigos 32 e 35 da LDBN para mencionar que os conhecimentos aprendidos na educação básica, no entendimento da Terceira Versão, levam o nome de competências. $\mathrm{O}$ fato é que hoje, esses artigos não dissertam nada sobre competências. Outro artigo mencionado é o 36, que baliza acerca do currículo do ensino médio e os itinerários formativos. A questão é que, ele, em si, não fala sobre competências, e sim o parágrafo 1, que traz os termos competências e habilidades, mas que não foi mencionado nessa Versão.

Para além dos dispositivos normativos, a Terceira Versão, na tentativa de também justificar a inserção do termo competências, afirmou que: a) ele é uma tendência na elaboração de reformas curriculares, em diferentes países no final do século XX e início do século XXI; b) que ele é adotado pelas avaliações internacionais da Organização para a Cooperação e Desenvolvimento Econômico (OCDE) que coordena o Programa Internacional de Avaliação de Alunos (PISA) e da Organização das Nações Unidas para a Educação, a Ciência e a Cultura (UNESCO), que instituiu o Laboratório Latino-americano de Avaliação da Qualidade da Educação para a América Latina (LLECE); c) que 10 Estados do Brasil analisados pelo Centro de Estudos e Pesquisas em Educação, Cultura e Ação Comunitária (CENPEC) já trazem uma visão de ensino com os termos competências e habilidades; e d) que as competências já apareciam nos PCN (BRASIL, 2017a).

Essa Versão omite o artigo 35-A, da Reforma do Ensino Médio, de 2017, da LDBN (1996), que menciona que a BNCC definirá direitos e objetivos de aprendizagem do ensino médio, conforme as diretrizes estabelecidas pelo Conselho Nacional de Educação, nas diversas áreas do conhecimento.

Pinheiro (2018), ao incursionar por Kuenzer (2001), verificou que o termo competências pode abarcar sentidos e significados distintos conforte a ênfase que se quer dar, o qual pode se relacionar a conceito de capital humano, à capacidade de agir articulando conhecimentos tácitos, científicos, entre outros.

Nesse sentido, poderíamos supor que, se no documento geral da BNCC-Terceira Versão consta a menção a dois documentos da Unesco ${ }^{8}$ (uma das agências internacionais que visam a uma formação voltada ao trabalho) e se no processo de composição da Base foi identificada,

\footnotetext{
${ }^{8}$ Um é o Glossário de Terminologia Curricular da UNESCO (UNESCO-UIS,2012) e o outro é um documento da mesma instituição de 2016 (BRASIL, 2016a).
} 
segundo Pinheiro (2018), a presença da Fundação Lemann, do Movimento Todos pela Educação-TPE e de demais sujeitos ligados ao governo e a entidades internacionais e/ou nacionais que, por sua vez, não diferem muito seus objetivos daqueles relacionados pela Unesco, podemos concluir que o sentido do termo competências, na educação física na BNCC, seria o mesmo. Entretanto, o componente educação física, ao trazer a cultura corporal de movimento, que tem um sentido e significado na cultura historicamente produzida pela humanidade, destoa da concepção dessas instituições e demais indivíduos, indicando uma outra possibilidade formativa, apesar de o documento geral e seus termos sinalizarem para outro caminho.

Ao entender as competências gerais da educação física como objetivos para a área, PC5V3 (2017, p. 3-4) alegou que eles deveriam apresentar, entre as intencionalidades, o provimento de "[...] jovens de conhecimento, competência, capacidade e excelência; [...] valores e atitudes", “[...] desenvolvimento pessoal, social, físico, emocional e intelectual [...]”; de "habilidades e aptidões"; e preparação "[...] para a proficiência em atividade física para a saúde ao longo da vida". PC4V3 $(2017$, p. 1) mencionou que a terceira competência do componente não deixou " [...] claro o que significa exatamente considerar uma prática corporal uma fonte de legitimação de acordos e condutas sociais". De fato, a nosso ver, essa competência $^{9}$ não está elucidativa, dificultando o entendimento por parte dos leitores, pincipalmente aqueles que colocarão em práticas as propostas curriculares, quais sejam, os professores. Por fim, P2V3 (2017, p. 21) relatou que a sequência das competências não segue uma ordem lógica e sugere sua alteração, iniciando por “[...] aquelas relacionadas aos 'saberes corporais' (mais específicos do componente) em direção a aqueles mais próximos a outros componentes curriculares".

A Versão Homologada, texto geral da BNCC, reafirma o compromisso com o termo competências e traz basicamente as mesmas justificativas ${ }^{10}$ para a inserção do termo. Essa terminologia também é levada à educação física, mas, a exemplo do que ocorre na Versão anterior, o componente não traz justificativas para a mudança.

\footnotetext{
${ }^{9}$ Na Terceira Versão, a terceira competência mencionada por PC4V3 (2017) traz o seguinte texto: "Considerar as práticas corporais como fonte de legitimação de acordos e condutas sociais, e sua representação simbólica como forma de expressão dos sentidos, das emoções e das experiências do ser humano na vida social.” (BRASIL, 2017a, p. 181).

${ }^{10}$ Nessa Versão, o texto geral da Base acrescenta apenas o artigo 35-A da LDBN, que menciona a nomenclatura direitos e objetivos de aprendizagem, e o parágrafo 1 do artigo 36, também da LDBN, que citava os termos competências e habilidades, os quais, haviam ficado fora da Terceira Versão. Esses dois dispositivos foram trazidos ao texto para informar que eles têm o mesmo entendimento.
} 
Em relação às competências específicas da educação física, nota-se a manutenção da maioria das que estavam descritas na Terceira Versão, com exceção daquela mencionada por PC4V3 (2017), que foi suprimida, e da última, que foi reescrita, mas nada que alterasse o seu sentido. A solicitação de P2V3 (2017) para que a sequência de competências se iniciasse por àquelas relacionadas aos 'saberes corporais', seguindo por àqueles próximos a outros componentes curriculares, não foi atendida. Foram incluídos certos valores e atitudes solicitados por PC5V3 (2017).

\subsection{Objetivos de Aprendizagem, Objetivos de Aprendizagem e Desenvolvimento e Habilidades por Prática Corporal}

A Versão Preliminar não traz explicações acerca das finalidades dos Objetivos de Aprendizagem Específicos por Prática Corporal, nem o porquê da escolha do termo. Ela apenas menciona que eles foram organizados em cinco ciclos ${ }^{11}$ e que eles têm a "[...] função de balizar as expectativas de aprendizagem no percurso curricular.” (BRASIL, 2015, p. 98). Assim, P5V1 (2016) afirmou haver necessidade de revisão do conjunto de objetivos e do espaço ocupado por eles, para que possam ser inseridos aspectos metodológicos e sequência didática. $\mathrm{Na}$ Segunda Versão, há acréscimo da palavra desenvolvimento para designar os objetivos, os quais, passam a ser nomeados como Objetivos de Aprendizagem e Desenvolvimento. Ao adotar essa terminologia, essa Versão atende ao PNE (2014) e a dois documentos da Unesco. Ao comparar a Versão anterior com essa, observa-se a revisão na escrita e na quantidade de objetivos. Para o ensino fundamental, houve aumento nos objetivos de algumas práticas e, em outras, houve diminuição ou manutenção da mesma quantidade.

Em relação às solicitações da Versão anterior, não se observa a indicação de aspectos metodológicos e sequência didática, requisitada por P5V1 (2016). Um dos motivos se deve ao fato de o documento ser visualizado como aberto, ou seja, como sugestão para o planejamento a ser realizado por várias escolas e redes de ensino.

Na Terceira Versão houve a inserção do termo Habilidades. No texto geral não há justificativa consistente para sua inserção, mas apenas uma explicação em nota de rodapé

\footnotetext{
11 Os ciclos definidos na Versão Preliminar foram: ensino fundamental anos iniciais, $1^{\circ}$ ciclo $\left(1^{\circ}, 2^{\circ}\right.$ e $3^{\circ}$ anos $)$ e $2^{\circ}$ ciclo ( $4^{\circ}$ e $5^{\circ}$ anos); ensino fundamental anos finais, $3^{\circ}$ ciclo $\left(6^{\circ}\right.$ e $7^{\circ}$ anos $)$ e 4 ciclo $\left(8^{\circ}\right.$ e $9^{\circ}$ anos $)$; e ensino médio $\left(1^{\circ}, 2^{\circ}\right.$ e $3^{\circ}$ anos) (BRASIL, 2015).
} 
mencionando que 10 Estados do Brasil ${ }^{12}$ apresentavam uma visão de ensino relacionada ao termo habilidades. Essa ação também fere a pactuação interfederativa proposta pelo PNE (2014) para o ensino fundamental. Devido a essa alternância, P2V3 (2017) e PC3V3 (2017) sugeriram a volta do uso do termo objetivos de aprendizagem e desenvolvimento. PC3V3 (2017) ainda proporam que se o termo objetivos não fosse reinserido no documento, que então, que se justificasse o termo habilidades.

P2V3 (2017, p. 23) ainda comentou ser “[...] conveniente a diminuição do número de objetivos de aprendizagem, reunindo 2 ou mais em um só, quando possível.”. No seu entendimento, essa redução, entretanto, “[...] não pode ser obtida a custo da qualidade em quesitos como: clareza, precisão e adequação conceitual'. Para ele, as habilidades não podem perder a capacidade de expressar precisamente as aprendizagens almejadas sobre uma determinada prática corporal.

A Versão Homologada segue com a mesma estrutura da anterior e não dispõe de justificativa para a adoção do termo habilidades no texto da educação física. Há a mesma quantidade de habilidades, mas com algumas alterações no documento, ou seja, a solicitação de P2V3 (2017) não foi atendida em sua integralidade. Observa-se também que não há menção a aspectos metodológicos e sequência didática, como requerido por P5V1 (2016).

Neira (2018) afirma que as habilidades previstas para o componente se aproximam da proposta de Bloom ${ }^{13}$ ao adotar a terminologia dimensões do conhecimento, a qual orienta a redação das aprendizagens pretendidas pela Base. Outra observação feita por esse autor é que nenhuma unidade temática traz habilidades que contemplem todas as 'dimensões' anunciadas. Para além disso, ele também menciona que não foram consideradas habilidades de reflexão sobre a ação, construção de valores e compreensão e, protagonismo comunitário, indicando que o domínio cognitivo suplantou os demais.

\subsection{Dimensões do Conhecimento}

Na Versão Preliminar, as Dimensões do Conhecimento são levadas para a BNCC sem nenhuma explicação. Conforme mencionado anteriormente, essas dimensões se aproximariam da proposta de Bloom. Os leitores críticos dessa Versão - P5V1 (2016), P4V1 (2016) e P3V1

\footnotetext{
12 Esses Estados formam analisados pelo Centro de Estudos e Pesquisas em Educação, Cultura e Ação Comunitária (CENPEC) (BRASIL, 2017a).

${ }^{13}$ Para entender melhor a proposta de Benjamin Bloom, ver BLOOM, B. Taxionomia de objetivos educacionais: domínio cognitivo. Porto Alegre: Globo; 1972.
} 
(2016) - relataram a necessidade de inserir detalhamentos e explicações acerca dessas dimensões. P5V1 (2016) também requisitou esclarecimentos sobre a teoria pedagógica que embasou os termos das dimensões. P3V1 (2016) comentou que as palavras utilizadas para elencar as dimensões não são comuns ao cotidiano dos professores, sugerindo que se elucide ou que se indique referências que possibilitem esse entendimento. E P4V1 (2016) considerou que a formulação dos objetivos por meio das dimensões favoreceu parcialmente a leitura e a compreensão dos diferentes conhecimentos do componente.

Na Segunda Versão, houve aumento na quantidade de dimensões, mas não foram feitos esclarecimentos quanto ao critério de inclusão, quanto à teoria pedagógica que deu embasamento a elas ou quanto à inserção de referências que permitissem o entendimento, conforme solicitado por P3V1 (2016), P4V1 (2016) e P5V1 (2016). No texto há apenas explicações referentes ao entendimento de cada uma delas.

Em relação à Terceira Versão, houve manutenção na quantidade de dimensões. As explicações passaram por revisão e algumas foram alteradas, mas nada que modificasse o seu sentido. Também não houve atendimento às solicitações de P3V1 (2016), P4V1 (2016) e P5V1 (2016). Para P4V3 (2017, p. 5), o destaque dado ao aspecto 'autoral' (na dimensão protagonismo comunitário) e à 'ampliação dos recursos para si e para os outros' gera dúvidas por não esclarecer se a proposta tem “[...] foco central o conteúdo com fim em si mesmo ou como meio para outros objetivos", pois, o assunto não ficou claro nem como posição e nem como desafio a ser perseguido. Já a dimensão "refletir sobre a ação" deveria ser reescrita, abrangendo "[...] uma reflexão crítica acerca dos usos e desusos do corpo na sociedade atual [...]” (P4V3, 2017, p. 14). PC7V3 (2017), por sua vez, entende que há articulação entre as dimensões do conhecimento do componente e os saberes trazidos pelo documento Delors, de 1996, pautado no "saber fazer, saber relacionar-se, saber sobre e saber apreciar".

Na Versão Homologada, as oito dimensões do conhecimento e o texto são os mesmos da Versão anterior. As críticas apresentadas por P4V3 (2017) não foram atendidas. Nota-se que há certa consonância entre as dimensões do conhecimento do componente e o saber fazer, saber relacionar-se, saber sobre e saber apreciar advindos do documento Delors, de 1996, e que também há relação com algumas competências gerais e algumas habilidades do componente curricular. Esses saberes não aparecem com essa terminologia, mas podem ser entendidos, de maneira contextual, como parte do processo. 


\subsection{Progressão do conhecimento ao longo das etapas}

Quanto à Progressão do Conhecimento ao longo das etapas e entre as etapas de escolarização - Versão Preliminar - o documento mencionou que qualquer prática corporal poderia ser trabalhada em qualquer etapa ou modalidade, entretanto, alguns critérios deveriam ser considerados, como:

[...] os elementos específicos das diferentes práticas corporais, as características dos sujeitos e os contextos de atuação, sinalizando tendências de organização dos conhecimentos que vão, das esferas sociais mais familiares às menos familiares, das temáticas mais frequentes às menos frequentes, das práticas corporais mais corriqueiras às menos comuns, de uma reflexão mais localizada a uma mais universal. (BRASIL, 2015, p. 97).

Desse modo, observa-se que não houve uma sequência única baseada em pré-requisitos e, sim, critérios pouco definidos, algo também mencionado por P1V1 (2016), a qual considerou que as transições ao longo das práticas corporais deveriam progredir levando em consideração “alguns critérios". P5V1 (2016) considerou importante destacar e enfatizar os principais elementos da cultura corporal em cada nível de ensino.

Na Segunda Versão, há acréscimo de informações e critérios acerca da progressão dos conhecimentos por prática corporal (embora nem todos os critérios sejam elucidativos). Notase o atendimento à solicitação de P1V1 (2016). Essas explicações também constam, para além do texto, ao lado dos quadros de objetivos, a fim de dirimir possíveis dúvidas, conforme demonstrado suscintamente no quadro 1.

Na Terceira Versão, há redução na textualização, pois os critérios de progressão foram brevemente relatados em um único parágrafo sem possibilitar esclarecimentos complementares. Nesse sentido, P4V3 (2017) relatou que os critérios utilizados para definir os objetos de conhecimento possuíam um caráter formal, que não houve flexibilidade ao longo do documento e que também não foram utilizados de forma explícita. Esse parecerista, assim como P3V3 (2017, p. 1), considerou importante “[...] a apresentação das classificações adotadas para cada prática corporal [...]" e a sua influência na progressão proposta.

P4V3 (2017, p. 15) também comentou que “[...] os critérios relacionados aos princípios e às características do desenvolvimento humano (físico, motor, perceptivo, cognitivo, social, afetivo), em particular, para a $3^{\mathrm{a}}$ infância e adolescência, não foram considerados [...]”. Em função do exposto, esse parecerista mencionou que, devido às diferentes classificações para as práticas corporais e características singulares, não houve a caracterização de uma base nacional, 
pois, em sua visão, deveria haver critérios de progressão que levassem em conta o princípio da continuidade dos conhecimentos e um modelo em espiral.

A abordagem cultural do movimento humano e o conceito de práticas corporais, na visão de P4V3 (2017), ampliaram e diversificaram o conhecimento, tornando-o subjetivo e abstrato. Contudo, isso não fez com que o conhecimento fosse sistematizado, além de eliminar abordagens pedagógicas que prezam pela aprendizagem do movimento e pelo ensino das modalidades esportivas tradicionais. Diante disso, P4V3 (2017) alegou que a proposta da BNCC também não atendeu às tradições fundantes da educação física. E, justamente pela sistematização não ser convencional, P3V3 (2017) relatou que seria importante que as lógicas (interna e externa) das práticas corporais fossem minimamente explicadas.

O princípio da continuidade dos conhecimentos implica em permitir que uma mesma prática corporal seja trabalhada em todos os ciclos de ensino de acordo com níveis de complexidade e reflexividade e, justamente, pela Base não propor isso é que PC3V3 (2017) criticaram o documento. Para eles, além da BNCC não propor isso, ela também não traz uma justificativa, havendo "[...] uma grande quantidade de práticas corporais em cada unidade temática, impossível de ser ensinada em apenas um ano escolar.” (PC3V3, 2017, p. 5). Dessa forma, eles sugerem “[...] que as seis unidades temáticas ${ }^{14}$ sejam abordadas em todos os anos, com objetos de conhecimento específicos para cada ano", levando "[...] em consideração as diferenças de desenvolvimento em todas as dimensões para cada faixa etária.” (PC3V3, 2017, p. 5).

De acordo com Pinheiro (2018), uma mesma prática corporal pode ser trabalhada em todos os anos, de acordo com o nível de complexidade, sempre estimulando as discussões e a criticidade em relação aos mais diversos assuntos. O problema é que, segundo Neira e Gramorelli (2017), esse sequenciamento é avesso do ponto de vista da cultura corporal no olhar pós-crítico ${ }^{15}$. Desse modo, se a Base está se guiando pela cultura corporal de movimento, os conhecimentos não deverão, necessariamente, ser trabalhados em espiral (do mais simples para

\footnotetext{
${ }^{14}$ As seis unidades temáticas citadas pelos pareceristas da Terceira Versão são: brincadeiras e jogos, esportes, ginásticas, danças, lutas e práticas corporais de aventura.

15 Segundo Neira e Gramorelli (2017, p. 329), “o ensino da Educação Física baseado nas teorias pós-críticas consiste na promoção do diálogo entre as múltiplas lógicas que atravessam os diferentes grupos que coabitam a sociedade e que veiculam seus significados por meio da cultura corporal". Eles ainda explicam que "assim como qualquer outro, esse conceito está em contínua reconstrução no jogo das relações de poder" e que quando as práticas corporais são transformadas em objeto de estudo, elas passam a ser "[...] vistas como artefatos culturais gerados no campo de disputas da cultura mais ampla, é o que lhes imprime os signos dos grupos sociais em que são criadas e recriadas". Dessa forma, "se estudantes e professores puderem entendê-las dessa forma, terão dado um passo decisivo para compreender o que acontece na sociedade".
} 
o mais complexo) e também não devem ser guiados por abordagens que prezem pelo movimento (com características do desenvolvimento humano).

Acerca desses apontamentos, faz-se importante mencionar que a BNCC não é um currículo e, sim, um documento orientador para que as escolas e redes tenham elementos que as auxiliem na composição de seus currículos, sinalizando para tendências de organização dos conhecimentos. Então, se a BNCC propusesse todas as condições requisitadas por P4V3 (2017), aí, sim, poderia perder a característica de uma base. Por outro lado, as sugestões de P4V3 (2017) poderiam facilitar o trabalho de professores se o princípio da continuidade dos conhecimentos se desse em espiral ${ }^{16}$, levando em consideração pré-requisitos ${ }^{17}$.

Por fim, na Versão Homologada, apesar das considerações e críticas dos pareceristas, os critérios de progressão das práticas corporais são os mesmos da Versão anterior, não havendo esclarecimentos adicionais na proposta sobre como cada critério fora empregado. Desse modo, as críticas de P4V3 (2017), P3V3 (2017) e PC3V3 (2017) não foram atendidas.

\section{Considerações Finais}

A análise da estrutura organizacional da educação física na Base Nacional Comum Curricular (BNCC), por meio de documentos e pareceres oficiais, levou-nos a identificar, inicialmente, a construção de um processo democrático que respeitava normativas e considerava solicitações advindas da consulta pública, de seminários governamentais e de pareceres. A mudança de governo, ocorrida em agosto de 2016, depois do lançamento da Segunda Versão, impactou diretamente no processo de composição da Base, no seu ideário, nas nomenclaturas e nos referenciais mencionados no documento.

Especificamente em relação às solicitações e críticas advindas dos pareceres e relatório da educação física - ensino fundamental, verificou-se que: a) algumas considerações foram aceitas; b) algumas demonstraram-se incoerentes ou conflituosas com a perspectiva da proposta e, portanto, não admitidas no texto; c) algumas foram aceitas e, depois, nas Versões seguintes,

\footnotetext{
${ }^{16}$ De acordo com Paraná (2008, p. 45), tratar de maneira espiral o conhecimento implica “[...] retomar, integrar e dar continuidade ao conhecimento nos diferentes níveis de ensino, ampliando sua compreensão conforme o grau de complexidade dos conteúdos". Significa dizer que um mesmo conteúdo "[...] pode ser abordado em diferentes níveis de ensino, desde que se garanta sua relação com aquilo que já foi conhecido, elevando esse conhecimento para um nível mais complexo.”.

${ }^{17}$ Esses pré-requisitos envolvem uma abordagem crescente de complexidade dos conhecimentos e que, segundo Soares et al. (1992), requerem tratamento dos conteúdos de forma simultânea e ampliação das referências do pensamento do aluno (ou seja, constatação de um ou vários dados da realidade, interpretação, compreensão e explicação).
} 
descontinuadas; d) outras podem ser identificadas nas entrelinhas ou, ainda, não serem visualizadas na textualização do componente, embora possam ser inseridas nas aulas de educação física pelo professor por fazerem parte do cotidiano escolar.

Em relação ao documento em si, de modo geral, foi possível constatar o aumento na textualização da BNCC em virtude das solicitações e, posteriormente, o enxugamento de informações da Terceira Versão. A falta da teoria que embasa o componente educação física e de esclarecimentos adicionais para a perspectiva da cultura corporal de movimento pode causar dúvidas ou confusões nos leitores, as quais podem ser sentidas, inclusive, na organização dos planejamentos das escolas e redes em relação progressão dos conhecimentos da área. Não há explicações quanto à inserção ou à teoria que embasa as dimensões do conhecimento e, embora haja explicações acerca de cada uma dessas dimensões, alguns termos não são comuns ao cotidiano dos professores, o que pode dificultar a compreensão das finalidades das habilidades.

Por fim, as mudanças na terminologia "objetivos de aprendizagem" para "objetivos de aprendizagem e desenvolvimento" deram-se para atender ao que propunha o PNE (2014). Contudo, homologou-se os termos competências e habilidades, materializados no texto geral da BNCC sob a justificativa de que eles constavam em certos documentos de organismos internacionais cujas orientações educacionais estão voltadas a uma formação superficial e ao trabalho. Essa ação poderia indicar que a educação física também estaria voltada a esses ideários, entretanto, o documento homologado, ao sinalizar que a formação está relacionada à cultura, precisamente à cultura corporal de movimento, tenta assegurar, embora com informações controversas, um outro ideal de formação escolar que se aproxima de um ensino democrático e de uma formação humana. Contudo, isso somente se efetivará se o professor possuir as condições educacionais necessárias para oportunizar, de fato, uma prática pedagógica voltada a essa finalidade.

\section{REFERÊNCIAS}

ANDERAOS, M. Contribuições - $\mathbf{3}^{\text {a }}$ Versão BNCC - 25/08/2017. Parecer Crítico enviado ao CNE, 2017.

BRACHT, V. Educação Física e aprendizagem social. Porto Alegre: Magister, 1992.

A constituição das teorias pedagógicas da educação física. Cadernos Cedes, ano XIX, no 48, ago., 1999. 
BRASIL. Plano Nacional de Educação - PNE. Lei n ${ }^{\circ} 13.005$, de 25 de junho de 2014. Disponível em: <http://www.planalto.gov.br/ccivil_03/_ato2011-2014/2014/lei/113005.htm>. Acesso em: 10 fev. 2020.

Base Nacional Comum Curricular - Versão Preliminar. Ministério da Educação. Setembro de 2015. Disponível em: <http://historiadabncc.mec.gov.br/documentos/BNCC-APRESENTACAO.pdf>. Acesso em: 12 mar. 2017.

Base Nacional Comum Curricular - $2^{\text {a }}$ Versão Revista. Ministério da Educação. Abril de 2016a. Disponível em: <http://basenacionalcomum.mec.gov.br/documentos/bncc-2versao.revista.pdf >. Acesso em: 12 mar. 2017.

. Números finais das contribuições propostas ao componente curricular Educação Física no documento preliminar da BNCC. $1^{a}$ Versão, 16 de março 2016, 2016 b.

Base Nacional Comum Curricular: Educação é a Base. Educação Infantil e Ensino Fundamental - $3^{\text {a }}$ Versão. Ministério da Educação. Abril, 2017a. Disponível em: <http://basenacionalcomum.mec.gov.br/images/BNCC_publicacao.pdf〉. Acesso em: 10 maio 2017.

Base Nacional Comum Curricular: educação é a Base. Educação Infantil e Ensino Fundamental - Versão Homologada. Ministério da Educação. Abril, 2017b. Disponível em: <http://basenacionalcomum.mec.gov.br/wpcontent/uploads/2018/04/BNCC_19mar2018_versaofinal.pdf>. Acesso em: 10 mai. 2019.

BARELA, J. A. Parecer Crítico - Base Nacional Comum Curricular: componente Educação Física. Leitura Crítica, 2017.

BRASILEIRO, L. T. Parecer sobre o documento Preliminar de Educação Física. Parecer crítico enviado ao MEC, fev., 2016.

CIAVATTA, M.; RAMOS, M. A "era das diretrizes": a disputa pelo projeto de educação dos mais pobres. Revista Brasileira de Educação, v. 17, n. 49, jan.-abr., 2012.

CONFEF. $3^{\circ}$ Parecer - 11/09/2017. Conselho Federal de Educação Física, Ofício 1221/2017, Parecer Crítico enviado ao CNE, 2017.

FRM/IP/IRM/PNUD/COLABORADORES. Leitura Crítica $-\mathbf{3}^{\mathbf{a}}$ Versão BNCC. Instituições: Fundação Roberto Marinho (FRM), Instituto Península (IP), Instituto Rodrigo Mendes (IRM), Programa das Nações Unidas para o Desenvolvimento (PNUD), Colaboradores: Edilson de Jesus Manoel, Guilherme Carvalho Franco da Silveira, Luis Henrique Martins Vasquinho, Tatiana Passos Zylberberg, Maria Eleni Henrique da Silva, Eduardo Mota e Silva, Parecer Crítico enviado ao CNE, 2017.

FRM/IP/IRM/PNUD/COLABORADORES. Leitura Crítica - $3^{\text {a }}$ Versão BNCC. Instituições: Fundação Roberto Marinho (FRM), Instituto Península (IP), Instituto Rodrigo Mendes (IRM), Programa das Nações Unidas para o Desenvolvimento (PNUD), Colaboradores: MANOEL, Edilson de Jesus; FREITAS, Amanda Fonseca Soares; SILVEIRA, Guilherme Carvalho Franco da; NICÁCIO, Luiz Gustavo; CAMPOS, Tulio; ALMEIDA, Admir Soares de; GOMES, Rodrigo Oliveira; VASQUINHO, Luis Henrique Martins; ZYLBERBERG, Tatiana Passos; NETO, Luiz Sanches; VENÂNCIO, Luciana; SILVA, Eduardo Mota. Parecer Crítico enviado ao CNE, out., 2017. 
GARIGLIO, J. A. Parecer sobre o documento preliminar do componente curricular da educação física na base nacional comum curricular. Parecer crítico enviado ao MEC, 2016.

GONZÁLEZ, F. J. Parecer sobre Base Nacional Comum Curricular Terceira Versão. Leitura Crítica, 2017.

KUENZER, A. Z. Conhecimento e competências no trabalho e na escola. Seminário Internacional de Educação-RS, v. 27, n. 2, mai.-ago. 2001.

LAKATOS, E. M.; MARCONI, M. de A. Fundamentos de metodologia científica: Técnicas de pesquisa. 7 ed. - São Paulo: Atlas, 2010.

LÜDKE, M.; ANDRÉ, M. E. D. A. Pesquisa em educação: abordagens qualitativas. São Paulo: EPU, 1986.

MANOEL, E. de J.; SILVEIRA, G. C. F. da; VASQUINHO, L. H. M.; ZYLBERBERG, T. P.; SILVA, M. E. H. da; SILVA, E. M. Leitura Crítica - 3 ${ }^{\text {a }}$ Versão BNCC. Parecer Crítico enviado ao CNE, 2017.

MINAYO, M. C. de S. (Org). Pesquisa social: teoria, método e criatividade. Petrópolis, RJ: Vozes, 1994.

MUNIZI, E. P.; ARRUDA, É. E. de. Políticas públicas educacionais e os organismos internacionais: influência na trajetória da educação especial brasileira. HISTEDBR On-line, n.28, p.258 -277, dez. 2007.

NEIRA, M. G. Teorias pós-críticas da educação: subsídios para o debate curricular da Educação Física. Dialogia, v. 2, n. 14, p. 195-206, 2011.

Incoerências e inconsistências da BNCC de Educação Física. Revista Brasileira de Ciências do Esporte, v. 40, n. 3, p. 215-223, 2018.

NEIRA, M. G.; SOUZA JÚNIOR, M. A Educação Física na BNCC: procedimentos, concepções e efeitos. Motrivivência, v. 28, n. 48, p. 188-206, setembro/2016.

NEIRA, M. G.; GRAMORELLI, L. C. Embates em torno do conceito de cultura corporal: gênese e transformações. Pensar a Prática, v. 20, n. 2, p. 321-332, 2017.

Teorias pós-críticas da educação: subsídios para o debate curricular da Educação Física. Dialogia, São Paulo, n. 14, p. 195-206, 2011.

NOGUEIRA, D. X. P. A educação a distância no brasil: da LDB ao novo PNE. In: $25^{\circ}$ Simpósio Brasileiro de Política e Administração da Educação e $2^{\circ}$ Congresso IberoAmericano de Política e Administração da Educação - ANPAE, abr. 2011, São Paulo, SP. Anais (on-line) São Paulo: Associação Nacional de Política e Administração da Educação, 2011. Disponível em:

<http://www.anpae.org.br/simposio2011/cdrom2011/PDFs/trabalhosCompletos/comunicacoe sRelatos/0124.pdf>. Acesso em: 20 jan. 2020. 
OLIVEIRA, D. A. As políticas educacionais no governo Lula: rupturas e permanências. RBPAE, v. 25, n. 2, p. 197-209, mai./ago., 2009.

OLIVEIRA. A. R. C. de. Parecer $3^{\text {a }}$ Versão - BNCC. Parecer Crítico enviado ao CNE, 2017.

ONU. OMS: $80 \%$ dos adolescentes no mundo não praticam atividades físicas suficientes. Nações Unidas Brasil. Disponível em: <https://nacoesunidas.org/oms-80-dos-adolescentesno-mundo-nao-praticam-atividades-fisicas-suficientes/>. Acesso em: 20 jan. 2020.

PANATHLON-FIEP. Parecer da $3^{\text {a }}$ Versão da BNCC - 25/08/2017. Panathlon Internacional Distrito Brasil - Federação Internacional de Educação Física - Brasil, Parecer Crítico enviado ao CNE, 2017.

PARANÁ. Diretrizes Curriculares da Educação Básica Educação Física. Governo do Paraná, Secretaria de Estado da Educação do Paraná, Departamento de Educação Básica, 2008. Disponível em:

<http://www.educadores.diaadia.pr.gov.br/arquivos/File/diretrizes/dce_edf.pdf>. Acesso em: 23 mar. 2020.

PINHEIRO, E. G. A Educação Física Escolar na Base Nacional Comum Curricular: dinâmicas de um movimento em construção. 2018. 382f. Dissertação (Mestrado em Educação Física) - Centro de Ciências da Saúde. Universidade Estadual de Maringá, Maringá, 2018.

REZER, R. Base Nacional Comum Curricular: horizontes para a educação básica - o campo da educação física em discussão... Parecer crítico enviado ao MEC, 2016.

RODRIGUES, A. T. Parecer Crítico da Versão Preliminar da Base Nacional Comum Curricular para a área de Linguagens, componente curricular - Educação Física. Parecer crítico enviado ao MEC, jan., 2016.

SANTOS, A. R. dos S. Metodologia Científica: A construção do conhecimento. Rio de Janeiro: DP\&A, 2000.

SOARES, C. L.; TAFFAREL, C. N. Z.; VARJAL, E.; CASTELLANI FILHO, L.; ESCOBAR, M. O.; BRACHT, V. Metodologia do Ensino de Educação Física. São Paulo: Cortez, 1992.

SOARES, M. G. Base Nacional Comum Curricular: parecer sobre o documento Preliminar de Educação Física. Parecer crítico enviado ao MEC, jan., 2016.

SOUZA, V. F. M. de. Parecer sobre o documento preliminar da BNC. Parecer crítico enviado ao MEC, 2016.

SOUZA JÚNIOR, O. M. de. Leitura crítica do texto de Educação Física da BNCC. Leitura Crítica, 2017. 
VIANNA, A. J. C. Parecer sobre Versão 3 da BNCC para Educação Física. Leitura Crítica, 2017.

WHO. Global recommendations on physical activity for health. World Health Organization, 2011. Disponível em: <https://www.who.int/dietphysicalactivity/physicalactivity-recommendations-5-17years.pdf $>$. Acesso em: 13 jan. 2020.

\section{SOBRE AS AUTORAS:}

\section{Ellen Grace Pinheiro}

Doutoranda pelo Programa de Pós-Graduação Associado em Educação Física UEM-UEL. Mestra pelo Programa de Pós-Graduação Associado em Educação Física UEM-UEL. Professora da Rede Básica de Educação do Paraná-Brasil. Integrante do Grupo de Pesquisa Corpo, Cultura e Ludicidade-DEF/UEM/CNPq e do Grupo de Estudos e Pesquisas em Educação Física Escolar. E-mail: ellen_gr@yahoo.com.br

iD http://orcid.org/0000-0001-8438-1717

\section{Vânia de Fátima Matias de Souza}

Doutora em Educação pelo Programa de Pós-Graduação em Educação da Universidade Estadual de Maringá-UEM (2014). Mestra em Educação Física pela Universidade Estadual de Maringá (2009). Professora no Departamento de Educação Física-DEF/UEM. Docente no Programa de Pós-Graduação em Educação da UEM. Coordenadora do Grupo de Estudos e Pesquisas em Educação Física Escolar GEEFE/UEM e Colíder do Grupo de Pesquisa Corpo, Cultura e Ludicidade-DEF/UEM/CNPq. E-mail: vfmatias@gmail.com

iD http://orcid.org/0000-0003-4631-1245

\section{Larissa Michelle Lara}

Doutora em Educação pela Universidade Estadual de Campinas (2004). Mestre em Educação Física pela Universidade Estadual de Campinas (1999). Professora Associada no Departamento de Educação Física da Universidade Estadual de Maringá. Docente no Programa de PósGraduação Associado em Educação Física UEM-UEL e no Mestrado Profissional em Educação Física em Rede Nacional (PROEF). Realizou Estágio Sênior Pós-doutoral na Universidade de Bath, Reino Unido (2016-2017 - Bolsista CAPES/Programas Estratégicos-DRI). Coordenadora do Grupo de Pesquisa Corpo, Cultura e Ludicidade-DEF/UEM/CNPq. Diretora Científica do Colégio Brasileiro de Ciências do Esporte e Editora-chefe da Eduem (Editora da Universidade Estadual de Maringá. E-mail: 1mlarauem@gmail.com

(iD http://orcid.org/0000-0001-9210-6360

Recebido em 27 de março de 2020 Aprovado em 13 de agosto de 2020 Publicado em 07 de setembro de 2020 